УДК $338.46: 37$

Лялюк Алла, кандидат економічних наук, доцент, Східносвропейський національний університет імені Лесі Українки, кафедра економіки, безпеки та інноваційної діяльності підприсмства, м. Луцьк; ORCID ID 0000-0002-4889-0511 e-mail: allalyalyuk@gmail.com

https://doi.org/10.29038/2411-4014-2020-02-99-106

\title{
ЗАРУБІЖНИЙ ДОСВІД ЗАСТОСУВАННЯ ІНФОРМАЦІЙНИХ ТЕХНОЛОГІЙ У БІРЖОВІЙ ДІЯЛЬНОСТІ
}

У статті досліджено зарубіжний досвід впливу інформаційних технологій на біржову діяльність світу; розглянуто приклади того, як інформаційна технологія змінила та сформувала поточний стан ринків, а також визначила його майбутній напрям; показано як інформаційні технології змінюють фінансові ринки, впливаючи на процес торгівлі починаючи від вибору активів і до сортування та обробки результатів аналізів торгів; описано етапи схеми біржових торгів: аналіз перед торгівлею, торговий «сигнал» та власне виконання торгів; представлено алгоритм схеми торгового процесу біржової торгівлі та відповідні моделі на кожному етапі; на прикладі біржі Nasdaq показано перехід до торгівлі, який залежить від високошвидкісної автоматизованої адаптаційної технології.

Ключові слова: інформаційна технологія, біржова діяльність. Фондова біржа, високочастотна торгівля, фінансові ринки

Лялюк Алла, кандидат экономических наук, доцент, Восточноевропейский национальный университет имени Леси Украинки, кафедра экономики, безопасности и инновационной деятельности предприятия, г. Луцк

\section{ЗАРУБЕЖНЫЙ ОПЫТ ПРИМЕНЕНИЯ ИНФОРМАЦИОННЫХ ТЕХНОЛОГИЙ В БИРЖЕВОЙ ДЕЯТЕЛЬНОСТИ}

В статье исследован зарубежный опыт влияния информационных технологий на биржевую деятельность мира; рассмотрены примеры того, как информационная технология изменила и сформировала текущее состояние рынков, а также определила его будущее направление; показано как информационные технологии меняют финансовые рынки, влияя на процесс торговли, начиная от выбора активов, сортировки и обработки результатов анализов торгов; описаны этапы схемы биржевых торгов: анализ перед торговлей, торговый «сигнал» и собственно выполнения торгов; представлены алгоритм схемы торгового процесса биржевой торговли и соответствующие модели на каждом этапе; на примере биржи Nasdaq показано переход к торговле, который зависит от высокоскоростной автоматизированной адаптационной технологии.

Ключевые слова: информационная технология, биржевая деятельность. Фондовая биржа, высокочастотная торговля, финансовые рынки

Lialiuk Alla, Associate Professor, Economics and Security of Enterprise Department, Lesia Ukrainka East European National University, Associate Professor, Ph.D. in Economics Lutsk,

\section{FOREIGN EXPERIENCE OF INFORMATION TECHNOLOGY APPLICATION IN EXCHANGE ACTIVITIES}

The article describes foreign experience of influence of information technologies on exchange activity of the world; exploitation of the latest technologies in making forecasts in the financial market based on the analysis of search queries on the Internet; and the priority directions of their application on the domestic stock market are determined. 
After engaging computer systems in stock trading, and later deciding whether to perform computer operations in self-selection and information processing, the concept of algorithmic trading or so-called computer trading was born

In order to understand algorithmic trading systems (ie computerized trading), the paper describes the process of trading on the stock exchange on the basis of three stages: pre-trade analysis (processing of information before using data or attracting news to analyze certain features of the market); trading "signal" (choosing the most optimal and profitable asset for bidding) and bidding itself. Pre-trading analysis includes: an alpha model (used to predict the future behavior of financial instruments); risk model and cost model that calculates future costs of trading in financial instruments. The rise of analytically sophisticated computing trading strategies shows that in recent years it has become commonplace for market participants to electronically search for agents and execute a transaction, all of which can be done in seconds. A new style of trading has emerged - high-frequency, where automated systems buy and sell financial instruments on an electronic platform, taking a certain position in just a few seconds. Described as Google search queries, the behavior and emotions of people on social networks can help predict the stock market situation.

The conclusion is made. that for capital market companies, technology provides the opportunity to get ahead and win by orienting the process in the right direction, adapting it to the needs of their own businesses. markets

Key words: information technology, stock market activity. Stock exchange, high frequency trading, financial

Постановка наукової проблеми та ії значення. Однією із сфер, яка стрімко розвиваються під впливом інформаційних технологій, є біржова діяльність. і зокрема, функціонування фондових бірж. Останні досягнення в галузі інформаційних технологій, такі як, хмарні обчислення, машинний інтелект, наука про поведінку та інші сфери, дають нам буквально прогнозувати завтрашній день i рухати біржовий ринок вперед новими способами.

Аналіз досліджень цієї проблеми. У вітчизняній науковій літературі проблеми діяльності бірж, зокрема фондових піднімали у своїх працях Вавдійчик I.М., Малишенко К. А. [1-2].Поряд 3 цим, питання впливу інформаційних технологій на розвиток біржової діяльності майже не досліджується, тоді як в економічно розвинутих країнах, дану проблематику піднімають неодноразово такі економісти як Лім К. П. (Lim K.-P.), Брукс P. (Brooks R.), де Луца M. (De Luca M.), Шостек Ш. (Szostek Ch.), Картлідж Дж. (Cartlidge J.), Дiаз С. (Diaz E.), Kipac M (Kearns M.), Кулеша A (Kulesza А.), Невмивака Ю. (Nevmyvaka Y.) та ін.[3-13, 15].

Мета і завдання статті. Метою статті $\epsilon$ ознайомитися із зарубіжний досвідом впливу інформаційних технологій на біржову діяльність світу; дослідити використання новітніх технологій у здійсненні прогнозу на фінансовому ринку на основі аналізу пошукових запитів в Інтернеті; описати процес перетворення запитів на необхідну інформацію та визначити пріоритетні напрями їх застосовування на вітчизняному біржовому ринку.

Виклад основного матеріалу Існують багато прикладів того, як інформаційна технологія змінила та сформувала поточний стан ринків, а також визначила майбутній напрямок. Але найвагомішими серед них Дж. Оуен (Jelf Owen), В.Джеймс (Burrows James), Д. Винн (Davies Wynn) у роботі «CAPITAL MARKETS TECHNOLOGY 2022» наводять такі:

- раціональне та автоматизоване використання (набір системних та автоматизованих технологій можуть забезпечити ефективний метод торгів та зменшити витрати);

- розширення каталогу залучених та проаналізованих даних, які створюють уявлення про потреби та поведінку клієнтів у реальному часі;

- відкритість і доступність (інформація про компанії стає більш прозорою);

- легка адаптативність (розробка «живого бізнесу», що може легко адаптуватися до будь-яких змін швидко та ефективно відповідно потребами ринку та споживачів);

- усунення зайвої складності по всьому процесу торгів, сортування та уникання витратних послуг, де це можливо [3].

Фондовий ринок - це один із найважливіших способів залучення грошей, який дозволяє публічно торгувати підприємствами та збирати додатковий фінансовий капітал, розширювати його шляхом продажу власних акцій компанії на публічному ринку. Посилаючись на історичні показники країн-світових лідерів, K.-P., Lim i R. Brooks зробили висновок, що ціна акцій та інших активів $\epsilon$ важливою частиною динаміки економічної діяльності i може впливати і бути показником соціального забезпечення населення. Фондовий ринок часто вважається основним показником економічної міцності та розвитку країни [4]. Останнім часом спостерігається дуже значне 
збільшення відсотків торгів на світових фінансових ринках, які здійснюються автоматизованими алгоритмічними системами для торгівлі - так званими «роботами», які самостійно виконують торгові ролі, які ще більше десяти років тому виконували люди. Група науковців з Брістольського університету М. Лука (M Luca), Ч. Шостек (Ch. Szostek) та ін. наводять достовірну інформацію, що на великих європейських біржах частка торгів, виконаних роботами, наближається до $50 \%$, а на основних біржових осередках США становить близько 75 \% [5].

Роль фондової біржі в економіці країни визначається насамперед рівнем «зрілості» торговоекономічних і фінансових відносин на базі капіталістичного ринку, ступенем розвитку ринку цінних паперів в цілому. Вітчизняні науковці Малишенко К. А., Вавдійчик I.М. та ін., факторами, які впливають на фондовий ринок, називають характер попиту і пропозиції; суб'єктивні чинники; ситуацію на суміжних ринках а також технічні фактори. Проте до технічних факторів відносять лише те, що пов'язане з технічною сферою цінних паперів, при цьому не уточнюючи, яку роль при цьому відіграють інформаційні технології. Однак, зазначають, що вираженою тенденцією, яка значно змінює «лице» біржової торгівлі, є зміни, викликані застосуванням комп'ютерів і сучасних інформаційних технологій у біржовій торгівлі., які дозволяють в режимі реального часу (он-лайн) здійснювати операції на фондовому і товарному ринках [1-2].

Після залучення комп'ютерних систем до біржової торгівлі, а пізніше прийняття рішення щодо виконання комп'ютерних операцій у самостійному відборі та обробці інформації, було розроблено автоматизовану систему виконання (AES - англ.). По мірі того, як AES ставала усе більш звичною і довіреною, різні торгові установи розпочали експериментувати з більш досконалими підходами до автоматизованого виконання: були розглянуті різноманітні методи і алгоритми, здатні відповідати вимогам для певних видів торгових угод за відповідних ринкових обставин. Таким чином. народилося поняття алгоритмічної торгівлі або так званої комп'ютерної торгівлі [6].

Заслуговує на увагу твердження Ч. Вандербурга (Ch. Vandenburgh), про те, що дослідження, періодичність та виконання - це три основні сфери, які змінилися у діяльності фондового ринку та інформаційних технологій. Зараз інвестори мають необмежену кількість доступу до інформації про підприємства та їх запаси, оскільки комп’ютерні системи швидко записують замовлення на купівлю або продаж необхідних акцій, то інвестори можуть за кілька секунд дізнатися їх ціну та інші необхідні дані. Фінансові консультанти тепер можуть передавати поточні події в режимі реального часу, і результатом цієї майже миттєвої інформації є більша поінформованість інвесторів, учасників біржових торгів та консультантів. Електронні торги усувають обробку операцій людьми, і тому помилки мінімізуються [7].

Віто Хенджото, директор консалтингової фірми «Zenifix», яка розробляє свій власний професійний та незалежний погляд щодо подій фінансовому ринку, повідомив, що найбільша зміна в фондових іграх, яку приносить технологія, полягає у тому, що учасник торгів більше не прив'язаний до робочого столу, як до робочого місця, адже тепер можна торгувати в дорозі через власний телефон або ноутбук. Раніше торги займали багато часу, використаний період доходив майже до 24 годин, а то й пару днів, тепер це ж саме можна зробити за декілька секунд і для цього потрібно лише доступ до Інтернету [9].

Для розуміння алгоритмічних торгових систем (тобто комп'ютерного торгу) спочатку потрібно побачити, як здійснюється торгівля на біржі, різні типи торгів та типи учасників. Зазвичай дилери виконують свої замовлення через загальний централізований ресурс замовлень, у якому перераховані замовлення на купівлю або продаж за певними видами цінних паперів, розподіленими за ціною та часом публікації замовлення. Процес торгів досить наочно описав Кліфф Д. (Cliff D..) у праці «Технологічні тренди на фінансовому ринку. Бачення до 2020» [6]. (Рис 1.) Відповідно до рис 1 , процес торгівлі проходить на основі трьох етапів. Перший етап - це аналіз перед торгівлею (оброблення інформації перед використанням даних або залучення новин для аналізу певних особливостей ринку). Другий - торговий «сигнал» (вибір найбільш оптимального та прибуткового активу для здійснення торгів). Третій - власне виконання торгів. Аналіз перед торгівлею включає: альфа-модель (використовується для прогнозування майбутньої поведінки фінансових інструментів); модель ризику (використовується для оцінки різних типів впливу та ризику); та модель витрат (вартості), яка розраховує майбутні витрати на торгівлею фінансовими інструментами. На етапі торгового сигналу є створення моделі, яка приймає результати з альфа-моделі, моделі ризику та 
моделі вартості транзакцій і вибирає «найкращий» варіант, при цьому вираховуючи як збільшити потенційний прибуток, обмежуючи при цьому ризик та витрати. Нарешті, на етапі виконання торгівлі модель виконання проводить необхідні торги найефективнішим способом [6].

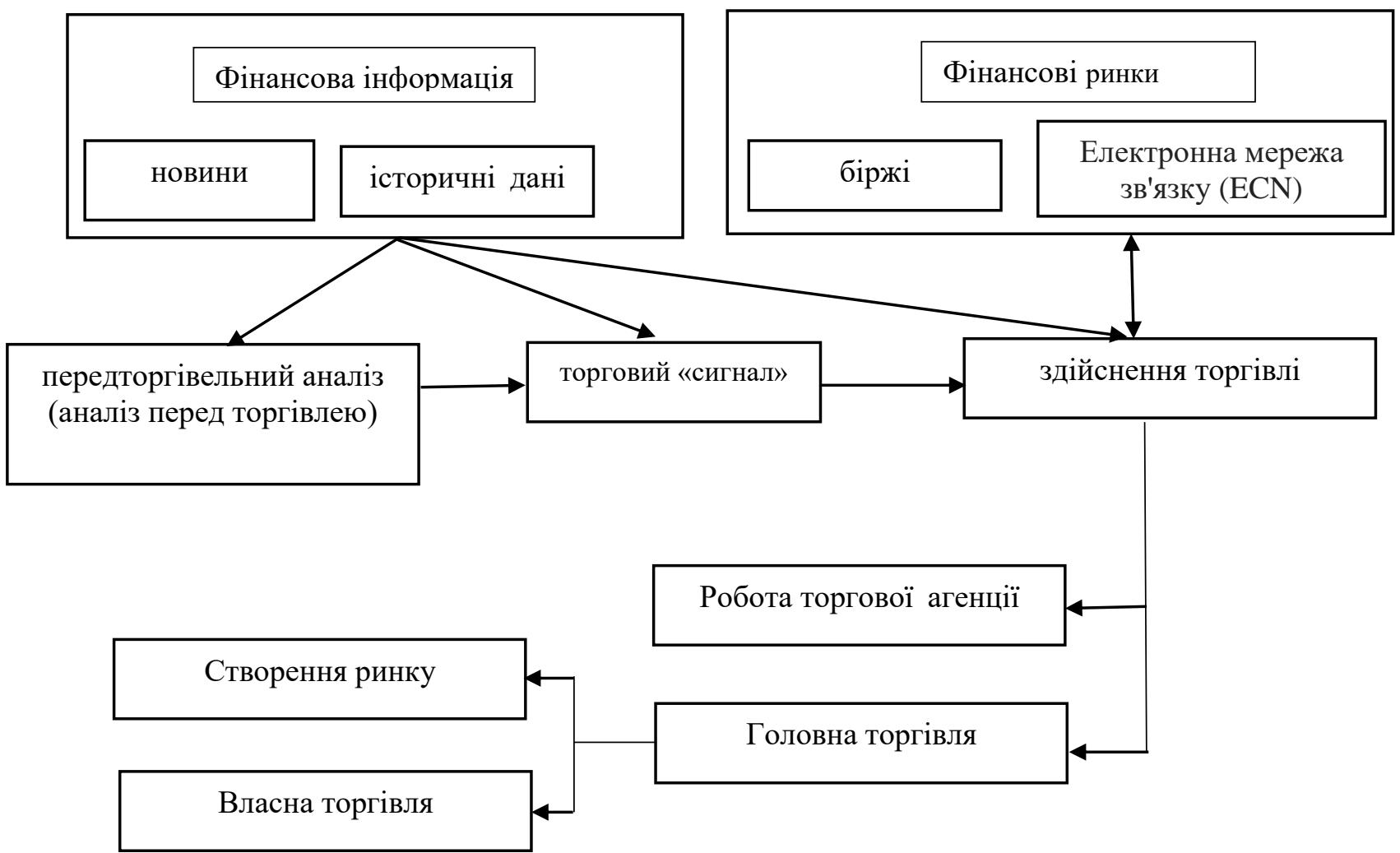

Рис 1. Схема торгового проиесу біржових торгів

Джерело: [7]

Зростання аналітично складних обчислювальних торгових стратегій, швидке автоматизоване виконання та доступ на ринок показують, що за останні роки стало звичним учасникам ринку в електронному вигляді шукати агентів, ідентифікувати зміст, а потім виконати транзакцію, і все це можна зробити протягом кількох секунд. Отже, з'явився новий стиль торгівлі, відомий як високочастотна торгівля (HFT - high-frequency trading), де автоматизовані системи купують i продають на електронних майданчиках фінансові інструменти, виконуючи певну позицію лише кілька секунд [10].

Перехід до торгівлі, який залежить від високошвидкісної автоматизованої адаптаційної технології спостерігається протягом останнього десятиліття. Сьогодні торгові системи можуть існувати в будь-якому місці і будь-який час. Необхідна лише доброякісна база даних, яка б спонукала торгувати у будь-якій частині світу та забезпечувала сприятливе середовище управління ризиками. Це глобальна вимога, і звичайно не усі фінансові ринки можуть конкурувати між собою, а тим більше бути лідерами у цій сфері. Наприклад, Nasdaq, одна 3 трьох основних фондових бірж США, прийняла новий стратегічний напрямок розвитку з урахуванням комп'ютерного майбутнього, надаючи перевагу таким бізнесам, як комп’ютерні технології та інформаційні послуги, які надають найбільші можливості для зростання. Середовище в якому ми живемо і працюємо, піддається технологічним пріоритетам, які включають чотири ключові тенденції:

- еволюція в купівлі та продажу активів з використанням біржових механізмів, що дозволяють вести переговори щодо ціни в режимі реального часу. Такі механізми є основою біржового бізнесу;

- популяризація інвестиційних банків, які демонструють реальну зацікавленість у роботі з Nasdaq або іншими біржами, для розробки нових технологій, які допоможуть розвинути їхній бізнес;

- управління інвестиціями стають все більш конкурентоспроможними із сильним акцентом на сферах, що працюють на технологіях [11]. 
У період постійних змін, розвитку та модернізації нових технологій науковці провели дослідження і виявили, що пошукові запити у Google, поведінка та емоції людей у соціальних мережах таких як Twitter чи Facebook можуть допомогти передбачити ситуацію на фондовому ринку. Тому розробляються та вдосконалюються програми для відстеження та аналізу запитів. Пошукова система Google надає доступ до сукупної інформації про обсяг запитів для різних пошукових термінів в тому числі і запити про фоновий ринок, та про те, як ці обсяги змінюються 3 часом (тиждень чи день) через загальнодоступний сервіс Google Trends. Щоб показати як працюють пошукові дані, та який вплив має поведінка людей на певний продукт, подію чи сферу, для прикладу наведемо часовий ряд пошуку в Google для слова Oktoberfest in Munich (рис.2).

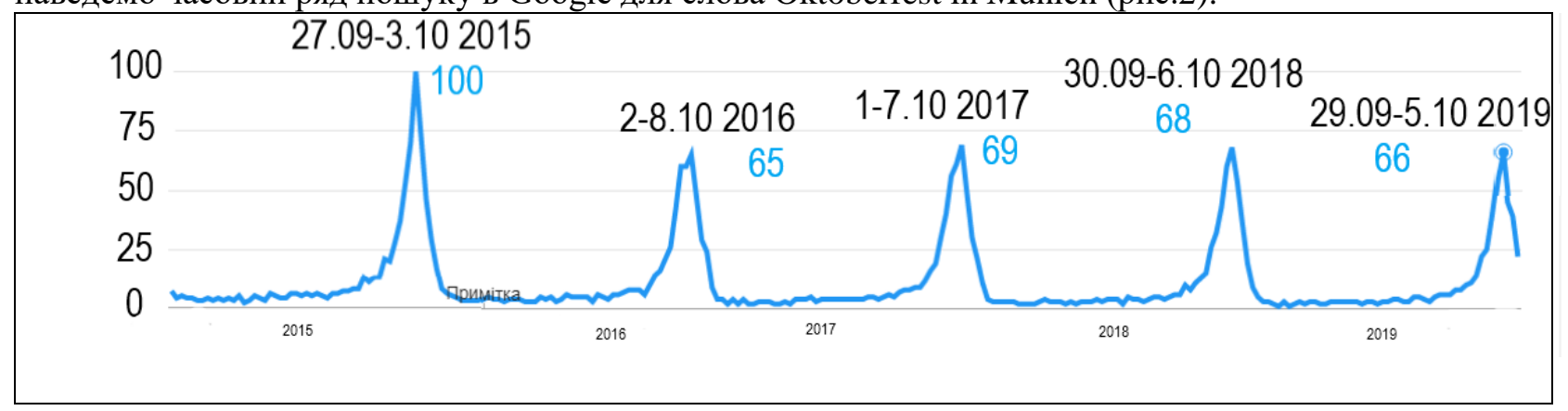

Trends

Рис. 2. Часовий ряд пошуку в Google для слова Oktoberfest in Munich.Приклад даних з Google

Джерело: [14]

Виділенні цифри показують популярність запитів відносно найвищої точки на графіку для певного регіону та періоду часу. 100 - це пік популярності терміну. 50 означає, що популярність терміну вдвічі менша. 0 означає, що було замало запитів про цей термін [14]. Із рис 2 видно, що дані 3 сайту Google Trends мають максимум 100, а решта значень виходять 3 цієї максимальної частоти. Ми також бачимо, що дані часових рядів мають сильний зріст на осінній період кожного року. I цей процес можна легко пояснити, оскільки, як правило, популярний німецький фестиваль «Oktoberfest» зазвичай починається 3 кінця вересня і до початку жовтня, що означає, що навколо цього періоду буде значна кількість пошукових запитів.

Відповідно до програм оброблення інформації та переведення Інтернет запитів в числовий генератор - стало відомо, чим більше запитів стає - тим популярнішою і дорожчою стає певна сфера, або ж навпаки - коли негативна інформація впливає на зниження курсу акцій. Прикладом може слугувати транспортний зв'язок, а саме аеропорт в Мюнхені. Не секрет, що ціна на квитки авіарейсів залежить від сезону, популярності напряму, тобто скільки запитів іде на певний рейс (якщо більше пошуків на сайті, то відповідно ціна зростає) та інших додаткових функцій. Оскільки нас цікавить чи впливає фестиваль, а саме пошукові запити в Інтернеті про транспортний зв'язок на курс акцій та зріст прибутку аеропорту на період кінця вересня - початку жовтня. Дослідження місцевих аналітичних компаній показало - що впливає, адже близько 6-7 мільйонів людей відвідують щорічно фестиваль пива в Мюнхені. Згідно з підрахунками організатора, позаминулорічний (2018 рік) «Октоберфест» збільшив місцеву казну на 1,23 мільярда євро. «Октоберфест» $є$ і залишається чітко «баварським» фестивалем. Більшість відвідувачів «Октоберфесту» - близько 71 відсотків приїжджають із району Баварія. Цей показник розподіляється на: 58 відсотків це жителі самого Мюнхена та 13 відсотків від решти Баварії. Ще 15 відсотків відвідувачів «Октоберфесту» приїжджають 3 інших частин Німеччини. Решта 14 відсотків відвідувачів фестивалю приїжджають зза кордону. Оскільки більшість іноземних відвідувачів користувались авіалініями і відповідно купували квитки до аеропорту Мюнхена відслідковується, що у період осені є збільшення прибутку даної установи, спершу зростають ціни через часті запити авіаквитків (можна відслідкувати скільки запитів було про даний аеропорт знаючи кількість пасажирів i використовуючи програми оброблення інтернет-запитів) і відповідно курс акції, а також прибуток аеропорту зростає [14].

Соціальні медіа надають велику кількість думок користувачів у реальному часі, зацікавлені організації можуть потенційно використати цю інформацію, використовуючи методи машинного навчання та природні технології обробки мови. У статті, опублікованій Університетом Пенсільванії: «Починаючи з 2008 року, багато фірм почали використовувати Twitter як форму передачі новин 
споживачам та інвесторам через свою привабливість і зосередженість на 140 символах, що дозволяють людям передавати коротку, цінну та швидку інформацію. Також 38 \% організацій у широкому діапазоні галузей планували витратити понад 20 \% від загального обсягу рекламних бюджетів на канали соціальних медіа у 2015 році [15]

Дослідники вивчали, чи впливають настрої користувачів, повідомлення та публікації відображені в соціальних мережах, на прибуток, окремі акції або на весь ринок чи спричиняють бум. Наприклад StockTwits - найбільша платформа мікроблогів для інвесторів та інвестиційних фахівців. Це дозволяє користувачам відстежувати конкретні фінансові активи, використовуючи хештеги (наприклад, \# stock, \#marketstock, \#business \#trend, \#selling, \#buing) у своїх повідомленнях. На основі цих хештегів було використано програму під назвою SentiStrength, щоб класифікувати кожне повідомлення як позитивне, негативне або нейтральне. Ці три категорії настрою можуть ефективно узагальнити думки користувачів мікроблогів щодо акцій [15]. Потім зібрали кількість позитивних /негативних повідомлень за певним періодом. Ця процедура аналізу настроїв генерувала часовий ряд позитивних та негативних балів настроїв для кожної акції. Спираючись на теорії та попередні висновки щодо фінансування на основі поведінки в Інтернеті, дослідники вважають що, хоча настрої інвесторів можуть передбачати майбутні прибутки, на це, ймовірно, впливатимуть i минулі прибутки. Визначені позитивні та негативні настрої мають різний вплив на інвесторів. Хоча було розроблено єдиний індекс настрою шляхом зважування позитивних та негативних настроїв, але доведено, що негативні настрої керують ринком у короткостроковій перспективі, а позитивні в довгостроковій.

Результати показують, що настрої користувачів на StockTwits значною мірою коливаються. Ефект сильніший на негативних настроїв, ніж від позитивних. Тобто негативні настрої посилюються після негативної віддачі (публікацій), ніж позитивні настрої після позитивної віддачі. Тим часом негативні настрої, але не позитивні, прогнозують повернення акцій протягом години (швидкий продаж), тобто після негативного допису в мережі акціонери будуть спродувати акції. Крім того, сильніший вплив негативних настроїв, відображає поведінки торговців так званим шумом, які більш чутливі до втрат, ніж до прибутків. Що стосується позитивних відгуків в мережі, то вони не спричиняють миттєвий бум купівлі акції, це зумовлено тим, що все ж таки інвестори обдумують свої рішення і не поспішають вкладати гроші покладаючись лише на швидку інформацію.

Висновки та перспективи подальшого дослідження. 3 появою нової торгової платформи відбулось підвищення ефективності ринку, збільшено кількість інвесторів, більше зареєстрованих компаній, швидша торгівля. Для компаній, що працюють у сфері ринків капіталу, технологія надає можливість випереджати та перемагати. Успішні вміють орієнтувати технологічний процес в правильному напрямку, пристосовувати його до потреб власного бізнесу та використовувати безперебійно. Інформаційні технології $\epsilon$ інструментом, який може забезпечити масштабний $\mathrm{i}$ швидкий доступ до розуміння та оброблення інформації. Результати вивчені під час написання статті показують, що соціальні дані, в даному випадку пошукові запити в Інтернеті, мають передбачувану силу щодо різних аспектів фінансових ринків, що підтверджують загальні результати, виявлені в попередніх дослідженнях іноземних вчених. Наявні дані в Google Trends або соціальних мережах можна використовувати як отримання аналізу та прогнозування про те, яка ситуація на фінансовому ринку. Відфільтрована необхідна інформація буде безпосередньо аналізувати поведінку людей і це допоможе інвесторам рід час прийняття рішень щодо купівлі або продажу акцій. Інвестори будуть знати про загальну географічну та політичну ситуацію і діятимуть на для покращення своїх фінансових результатів.

\section{Джерела та література}

1. Вавдійчик I. М. Сучасний стан та тенденції розвитку біржової торгівлі в Україні / І. М. Вавдійчик [Електронний ресурс] :- Режим доступу: h ttp://global-national.in.ua/archive/15-2017/36.pdf

2. Малишенко К. А. Фактори, що визначають особливості фондового ринку / К. А. Малишенко [Електронний ресурс] :- Режим доступу http:// old.bumib.edu.ua/ sites/default/ files/visnyk/25_1.pdf

3. HOW TECHNOLOGY IS AFFECTING THE FINANCIAL MARKETS //Wall Street, Jan $29,2019$. [Електронний ресурс]:- Режим доступу: https://wall-street.com/how-technology-is-affecting-the-financial-markets/. 
4. Lim K.-P.The Evolution of Stock Market Efficiency Over Tie: A Survey of the Empirical Literature / K.-P. Lim, R. Brooks R// Journal of Economic Surveys, 2010. [Електронний ресурс]: - Режим доступу https:// onlinelibrary. wiley.com/ doi/abs/ 10.1111/j.1467-6419.2009.00611.x

5. De Luca Marco. Studies of Interactions Between Human Traders and Algorithmic Trading Systems / Marco De Luca Marco, Charlotte Szostek, John Cartlidge, Dave Cliff //Department of Computer Science, University of Bristol, 2011. [Електронний ресурс] :- Режим доступу: https:// pdfs.semanticscholar.org/ 711e/ f95dfa87 3e06274df 93fd12c2b766078a837.pdf

6. Cliff Dave. Technology Trends in the Financial Markets: A 2020 Vision / Dave Cliff, Dan Brown, Philip Treleaven. [Електронний pecypc]: - Режим доступу: https://www.researchgate.net/ publication/ 313371531_Technology_Trends_in_the_Financial_Markets_A_2020_Vision .

7. Vandenburgh Christa. The Impact of Technology on the Stock Market / Christa Vandenburgh [Електронний pecypc]: - Режим доступу: https:// bwstewart.wordpress.com/ 2018/03/19/the-impact-of-technology-on-the-stockmarket/.

8. Johnston Kevin. The Impact of Technology on the Stock Market / Kevin Johnston [Електронний ресурс] :Режим доступу: https:/ /www.zacks.com/s earch.php?q=Kevin+Johnston

9. Diaz Eva. How Technology is Changing the Way You Trade / Eva Diaz //website offering online financial trading news - Finance Magnates [Електронний ресурс] : - Режим доступу: https://www.financemagnates.com/.

10. Kearns M. Empirical Limitations on High Frequency Trading Profitability / M. Kearns, A. Kulesza, Y. Nevmyvaka // Journal of Trading, 2010. [Електронний pecypc]: - Режим доступу: http:// www.cis.upenn.edu/ mkearns/ papers/ hft_arxiv.pdf.

11. Arnuk S. Broken Markets: How High Frequency Trading and Predatory Practices on Wall Street are Destroying Investor Confidence and Your Portfolio / S. Arnuk, J. Saluzzi [Електронний ресурс]: - Режим доступу: http:// ptgmedia.pearsoncmg.com/ images/9780132875240/samplepages/0132875241.pdf

12. Jelf Owen. CAPITAL MARKETS TECHNOLOGY 2022 / Owen Jelf, James Burrows, Wynn Davies. [Електронний ресурс]: - Режим доступу: https://www.accenture.com/_acnmedia/pdf-69/accenture-capital-marketstechnology-2022.pdf.

13. Preis T. Stanley Quantifying Trading Behavior in Financial Markets Using Google Trends / T.Preis, $\underline{\mathrm{H}}$. Susannah Moat, H. Eugene II Scientific Reports 3, 1684 (2013) [Електронний ресурс]: - Режим доступу: https://www.nature.com/articles/srep01684

14. Фінансовий звіт Мюнхенського аеропорту https:// www.munich-airport.com/ b/0000000000000006771266bb5d10d6da FMG_IB2018_Financial-report.pdf

15. Deng .Sh., The Interaction between Microblog Sentiment and Stock Return: An Empirical Examination ./.Shuyuan Deng, Zhijian (James) Huang, Atish P Sinha Huimin Zhao. September 1, 2018 [Електронний ресурс]: Режим доступу: https://papers.ssrn.com/sol3/papers.cfm?abstract_id=3054906

\section{References}

1. Vavdiichyk I. M. (2017)Suchasnyi stan ta tendentsii rozvytku birzhovoi torhivli v Ukraini [Current state and tendencies of development of stock exchange trade in Ukraine] Retrieved from:: http://globalnational.in.ua/archive/15-2017/36.pdf [in Ukrainian].

2. Malyshenko K. A. Faktory, shcho vyznachaiut osoblyvosti fondovoho rynku (n.d) [Factors that determine the features of the stock market] Retrieved from http:// old.bumib.edu.ua/ sites/default/ files/visnyk/ 25_1.pdf [in Ukrainian].

3. HOW TECHNOLOGY IS AFFECTING THE FINANCIAL MARKETS (Jan 29, 2019 [Wall Street] Retrieved from: https://wall-street.com/how-technology-is-affecting-the-financial-markets/ [in England]

4. Lim K.-P., Brooks R. (2010). The Evolution of Stock Market Efficiency Over Tie: A Survey of the Empirical Literature [Journal of Economic Surveys]. Retrieved from: https://onlinelibrary.wiley.com/doi/abs/10.1111/j.14676419.2009.00611.x [in England].

5. De Luca Marco, Szostek Charlotte, Cartlidge John, Cliff Dave (2011) Studies of Interactions Between Human Traders and Algorithmic Trading Systems. [Department of Computer Science, University of Bristol]. Retrieved from: https://pdfs.semanticscholar.org/711e/f95dfa873e06274df93fd12c2b766078a837.pdf [in England].

6. Cliff Dave, Brown Dan, Treleaven Philip. (2010). Technology Trends in the Financial Markets: A 2020 Vision.Retrievedfrom:https://www.researchgate.net/publication/313371531_Technology_Trends in the Financial_Ma rkets_A_2020_Vision [in England].

7. Vandenburgh Christa (2018). The Impact of Technology on the Stock Market. Retrieved from:https://bwstewart.wordpress.com/ 2018/03/19/the-impact-of-technology-on-the-stock-market/ [in England].

8. Johnston Kevin. (n.d) The Impact of Technology on the Stock Market. Retrieved from: https://www.zacks.com/ search.php?q=Kevin+Johnston [in England]. 
9. Diaz Eva (2016). How Technology is Changing the Way You Trade. [website offering online financial trading news - Finance Magnates]. Retrieved from: https://www.financemagnates.com/ [in England].

10. Kearns M., Kulesza A., Nevmyvaka Y. (2010). Empirical Limitations on High Frequency Trading Profitability. [Journal of Trading]. Retrieved from:http://www.cis.upenn.edu/ mkearns/papers/hft_arxiv.pdf. [in England].

11. Arnuk S., and Saluzzi J. (2012) Broken Markets: How High Frequency Trading and Predatory Practices on Wall Street are Destroying Investor Confidence and Your Portfolio. Retrieved from: http:// ptgmedia.pearsoncmg.com/ images/9780132875240/samplepages/0132875241.pdf [in England].

12. Jelf Owen, Burrows James, Davies Wynn. (2018). CAPITAL MARKETS TECHNOLOGY 2022 Retrieved from: https://www.accenture.com/ acnmedia/pdf-69/accenture-capital-markets-technology-2022.pdf [in England].

13. Tobias Preis, Helen Susannah Moat, H. Eugene. (2013). Stanley Quantifying Trading Behavior in Financial Markets Using Google Trends. Retrieved from: https://www.nature.com/articles/srep01684[in England].

14. Financial Report of Munich Airport (2018) Retrieved from: https://www.munichairport.com/_b/0000000000000006771266bb5d10d6da/FMG_IB2018_Financial-report.pdf [in England].

15. Shuyuan Deng, Zhijian (James) Huang, Atish P Sinha Huimin Zhao (2018) The Interaction between Microblog Sentiment and Stock Return: An Empirical Examination Retrieved from: https://papers.ssrn.com/sol3/papers.cfm?abstract id=3054906 [in England].

Стаття надійшла до редакції 15.05.2020 р. 